This is an Open Access article distributed under the terms of the Creative CommonsAttribution 4.0 International License which permits unrestricted noncommercial use, distribution, and reproduction in any medium, provided the original work is properly cited.

\title{
THE DIFFERENCE OF QUALITY OF LIFE ON PATIENTS OF DIABETES MELLITUS BETWEEN GIVING HYPERBARIC OXYGEN THERAPY 10 DAYS AND 5 DAYS
}

\author{
Mufarika $^{1}$, Siti Aminah ${ }^{1}$ \\ Emergency Department School of Health Ngudia Husada of Madura \\ mufarika.unpad@gmail.com
}

\section{ABSTRACT}

Keywords

Quality of life is the subjective perception of the individual to the physical, psychological, social, and environmental conditions experienced. The aim of the study was to analyze quality of life of diabetes mellitus patients between providing hyperbaric oxygen therapy 10 days and 5 days.

This study used the quasy experiment method with the approach of pre post test with control group design. The population in the study was 882 people with a sample of 40 respondents divided into two groups, 25 respondents in the treatment group and 25 respondents in the control group. Sampling used was systematic random sampling techniques. Data were analyzed using Paired $t$ test and Independent t test.

The results of the Paired t test statistic in the treatment group had differences in quality of life before and after 10 days of hyperbaric oxygen therapy, while the control group had no difference in quality of life before and after 5 days of hyperbaric oxygen therapy. The independent $t$ test results were different after being given hyperbaric oxygen therapy 10 days and 5 days.

It is expected that health workers can be used as a reference source and as a basis for determining nursing intervention in the management of diabetes, especially in the quality of life of diabetic patients. 


\section{BACKGROUND}

Quality of life is the subjective perception of the individual to the physical, psychological, social, and environmental conditions experienced in everyday life that sometimes become a health problem. Quality of life can also be experienced in various situations in human life, one of which is in the world of health. One disease that can have an impact on quality of life is diabetes mellitus. Diabetes mellitus is a group of metabolic diseases with characteristic hyperglycemia that occurs due to abnormal insulin secretions, insulin work disorders or both, which cause various chronic complications in the eyes, kidneys, nerves and blood vessels (Brunner \& Suddarth, 2013).

The quality of life in good physical dimensions is a level that describes the superiority of a patient with diabetes mellitus who can be assessed from the physical aspects of their lives such as things related to it include daily activities, dependence on medical materials or medical help, energy and rest, and work capacity (Jang, Hsieh, Wang, \& Wu, 2004 and Yusra, 2011).

Diabetes is connected with vascular complications, and in international and national guidelines the overall goal for the treatment of all diabetes is to prevent acute and chronic complications, while preserving a good quality of life for the patient. Thus, knowledge concerning Quality of life in diabetic patients, as well as the determinants of this, is crucial (Wändell, 2005).

According to WHO (2015) as many as 415 million adults with diabetes mellitus, a 4fold increase from 108 million in the 1980s. In 2040 it is estimated that the number will be 642 million (Ogurtsova et al, 2015). In 2015 , the presentation of adults with diabetes mellitus was $8.5 \%$ ( 1 in 11 adults with diabetes). Based on the 2013 Basic Health Research (Riskesdas) in Indonesia there were 10 million people with diabetes mellitus. East Java Province is one of the regions in Indonesia with a prevalence of $2.1 \%$ of diabetes mellitus patients (Riskesdas 2013). Based on data obtained from the East Java Provincial Health Office (2012) based on 10 most disease patterns in outpatients in type B hospitals Diabetes mellitus is the second largest disease after hypertension, which is 102,399 cases.

Based on a preliminary study of 10 respondents at LAKESLA TNI AL Drs. Med. R. Rijadi S., Phys Surabaya found that 5 people with worse quality of life, were not satisfied with their health, experienced limitations in activities, needed medical therapy to function in daily life and did not feel satisfied in sleep and the ability to work. Five people with sufficient quality of life, namely having enough vitality to do their daily activities, experience limitations in activities, need medical therapy to be able to function in daily life. Hence this study, aimed to analyze quality of life of diabetes mellitus patients between providing hyperbaric oxygen therapy 10 days and 5 days

\section{RESEARCH METHODOLOGY}

The study population was all diabetes mellitus patients who were in LAKESLA TNI AL Drs. Med. R. Rijadi S., Phys Surabaya $(N=882)$. The sample in the study was diabetes mellitus patients who first received hyperbaric oxygen therapy totaling 25 people in the treatment group and 25 people in the control group, with inclusion criteria is patients with diabetes mellitus and first received Hyperbaric Oxygen Therapy. Exclusion criteria are patients with heart, lung, kidney disorders, claustrophobia and patients with decreased consciousness.

This study used probability sampling with systematic random sampling techniques. This study the research design used was the quasy experiment with pre and post test design with control group. The tool used in data collection is a life quality questionnaire (WHOQOL)-Bref and tested 
by paired t-test statistical tests and independent t-test with a significance level of 0.05 with the scale of the data used is the ratio.

\section{THE RESULT OF STUDY}

Table 1. Quality of life in Treatment Groups (10 days) in LAKESLA TNI AL Drs. Med. R. Rijadi S., Phys Surabaya.

\begin{tabular}{lcccc}
\hline \multirow{3}{*}{ Domain } & \multicolumn{2}{c}{ Pre } & \multicolumn{2}{c}{ Post } \\
& \multicolumn{2}{c}{ Treatment } & \multicolumn{2}{c}{ Treatment } \\
\cline { 2 - 5 } & Mea & SD & Mea & SD \\
& $\mathrm{n}$ & & $\mathrm{n}$ & \\
\hline Physical & 46.2 & 8.89 & 54.2 & 8.24 \\
& 8 & & 8 & \\
\hline Psychologic & 48.0 & 9.78 & 56.3 & 7.71 \\
al & 0 & & 3 & \\
\hline Social & 45.3 & 11.0 & 53.3 & 10.7 \\
Relations & 3 & 4 & 3 & 5 \\
\hline Environment & 42.7 & 8.40 & 50.1 & 7.57 \\
& 5 & & 3 & \\
\hline
\end{tabular}

Based on a scale of 0-100, the score of each quality of life domain before hyperbaric oxygen therapy has a mean between 42.75 48.00 , and after hyperbaric oxygen therapy the score for each quality of life domain has a mean between 50.13-56.33.

Table 2. Quality of life in Control Groups (5 days) in LAKESLA TNI AL Drs. Med. R. Rijadi S., Phys Surabaya.

$$
\text { Pre Post }
$$

\begin{tabular}{lcccc}
\multirow{2}{*}{ Domain } & \multicolumn{2}{c}{ Treatment } & \multicolumn{2}{c}{ Treatment } \\
\cline { 2 - 5 } & Mea & SD & Mea & SD \\
& $\mathrm{n}$ & & $\mathrm{n}$ & \\
\hline Physical & 46.5 & 8.21 & 49.1 & 7.08 \\
& 7 & & 4 & \\
\hline Psychologic & 48.1 & 8.67 & 50.1 & 78.7 \\
al & 6 & & 6 & 9 \\
\hline Social & 44.0 & 11.4 & 46.6 & 11.0 \\
Relations & 0 & 1 & 6 & 2 \\
\hline Environment & 41.7 & 9.45 & 44.5 & 9.03 \\
& 5 & & 0 & \\
\hline
\end{tabular}

Based on a scale of 0-100, the score of each quality of life domain before hyperbaric oxygen therapy has a mean between 41.75 48.16 , and after hyperbaric oxygen therapy the score for each quality of life domain has a mean between 44.00-50.16.

Table 3. Differences in Quality of Life Given by Hyperbaric Oxygen Therapy in Treatment and Control Groups at LAKESLA TNI AL Drs. Med. R. Rijadi S., Phys Surabaya.

\begin{tabular}{|c|c|c|c|}
\hline Groups & Days & Mean & $\begin{array}{c}\text { Sig. } \\
\text { (2-tailed) }\end{array}$ \\
\hline \multirow[t]{2}{*}{ Physical } & 5 Days & 49.14 & \multirow[b]{2}{*}{.022} \\
\hline & $\begin{array}{l}10 \\
\text { Days }\end{array}$ & 54.28 & \\
\hline \multirow[t]{2}{*}{ Physiological } & 5 Days & 50.16 & \multirow[b]{2}{*}{.011} \\
\hline & $\begin{array}{l}10 \\
\text { Days }\end{array}$ & 56.33 & \\
\hline \multirow{2}{*}{$\begin{array}{l}\text { Social } \\
\text { Relations }\end{array}$} & 5 Days & 46.66 & \multirow[b]{2}{*}{.036} \\
\hline & $\begin{array}{l}10 \\
\text { Days }\end{array}$ & 53.33 & \\
\hline \multirow[t]{2}{*}{ Environment } & 5 Days & 44.50 & \multirow[b]{2}{*}{.021} \\
\hline & $\begin{array}{l}10 \\
\text { Days }\end{array}$ & 50.12 & \\
\hline
\end{tabular}

Based on the analysis of the Independent ttest in the treatment group and the control group it can be concluded that there were differences after 10 consecutive days of hyperbaric oxygen therapy and 5 consecutive days of hyperbaric oxygen therapy.

\section{DISCUSSION}

The difference of the quality of life on patients with diabetes mellitus before and after being given hyperbaric oxygen therapy for 10 days

The results showed that there were differences in the quality of life before and after being given hyperbaric oxygen therapy for 10 days at the LAKESLA TNI AL Drs. Med. R. Rijadi S., Phys Surabaya. Hyperbaric oxygen therapy has a pressure greater than nominal air which can increase oxygen saturation in the body. When high oxygen supply plays an important role in 
metabolic processes in the body. The general goal is to provide more oxygen saturation to the body's vascularization. This metabolic process can produce energy. The energy produced can be used for one's activities and to improve the quality of life.

In this study, age is one of the factors that can affect the quality of life of the physical dimension in patients with diabetes mellitus. The results of the study also showed that the majority of respondents were 51-60 years old (57.1\%). At that age, physiological changes, organ systems and glucose intolerance and the aging process occur. This is supported by the theory (Yusra, 2011) which states that most patients with diabetes mellitus are adults over the age of 40 years. This is because insulin resistance in type 2 diabetes mellitus will tend to increase at the age of 40-65 years. Increased risk of diabetes occurs with age, especially those over 45 years old. At this age, glucose intolerance begins and the aging process causes reduced ability of the pancreatic $\beta$ cells to produce insulin (Sunjaya, 2009).

As stated by Huda (2010), hyperbaric oxygen has an effect on wound perfusion in diabetic mellitus patients assessed from akral, CRT and Oxygen Saturation where the administration of oxygen with a pressure of more than 1 (one) atmosphere, carried out in the High Pressure Air Chamber (RUBT). Air pressure increases up to three times higher than normal air pressure. Under these conditions, the lungs can collect more pure oxygen inhaled. Blood flow will carry oxygen throughout the body and stimulate the release of substances called stem cells which will then stimulate the healing process. With high pressure conditions, it is expected that oxygen saturation increases and the cellular matrix that supports life gets optimal conditions. So that it can improve the quality of one's life.

In this study one of the factors that can affect the quality of life is the treatment schedule 10 times for hyperbaric oxygen therapy of diabetes mellitus, This schedule has been shown to be safe for scuba divers and our study showed it tobe safe in our diabetic patients (Löndahl, Katzman, Nilsson, \& Hammarlund, 2010). Diabetes mellitus also influencing of duration of the disease. The results of the analysis showed that some of the respondents $5(71.4 \%)$ had suffered from diabetes mellitus for 1-5 years. Long suffering from diabetes mellitus can be one of the factors that affect quality of life which can be related to the level of anxiety which will result in a decrease in the quality of life of patients with diabetes mellitus. Because the longer the patient suffers from the disease, the lower the quality of life of the patient.

This is in line with the research of TullochReid \& Walker (2010) which states that the duration of suffering from diabetes mellitus is significantly associated with anxiety levels so that it will result in a decrease in the quality of life of patients with diabetes mellitus. Likewise with the Kalda (2011), it was stated that the duration of diabetes mellitus was significantly associated with the quality of life of patients with diabetes mellitus, which generally had a low quality of life in the long duration of diabetes mellitus.

\section{The difference quality of life on the control group of patients with DIABETES MELLITUS before and after being given hyperbaric oxygen therapy for 5 days}

The results showed that there were differences in the quality of life before and after being given hyperbaric therapy for 5 days at the LAKESLA TNI AL Drs. Med. R. Rijadi S., Phys Surabaya. Based on the data obtained that the quality of life of patients before being given hyperbaric oxygen therapy were found that all experienced a low quality of life. Giving 10 days of action is more effective than giving 5 days of action.

One of the factors that can affect the quality of life of the physical dimension in patients with diabetes mellitus is age. The results of the study also showed that almost half of the respondents were aged 51-60 years $(57.1 \%)$. At that age, physiological 
changes, organ systems and glucose intolerance and the aging process occur. This is supported by the theory (Yusra, 2011) which states that most patients with diabetes mellitus are adults over the age of 40 years. This is due to insulin resistance in type 2 diabetes mellitus will tend to increase at age 40-65 year. Increased risk of diabetes occurs with age, especially those over 45 years of age. At this age, glucose intolerance begins and the aging process causes reduced ability of the pancreatic $\beta$ cells to produce insulin (Sunjaya, 2009).

In this study, one of the other factors that can affect low quality of life is the length of diabetes mellitus. It is known that in the treatment group long period suffering from diabetes mellitus, most of the respondents were $5(71.4 \%)$ for $1-5$ years. While in the control group almost all respondents were 6 (85.7\%) for $1-5$ years. Long suffering from diabetes mellitus can be one of the factors that affect quality of life which can be related to the level of anxiety which will result in a decrease in the quality of life of patients with diabetes mellitus.

One of the triggers of respondents who still have no improvement in quality of life or respondents with a low quality of life category can be caused by the duration of diabetes mellitus. Because the longer the patient suffers from the disease, the lower the quality of life of the patient. This is in line with the research of Tulloch-Reid \& Walker (2010) which states that the duration of diabetes mellitus is significantly associated with anxiety levels so that it will result in a decrease in the quality of life of patients with diabetes mellitus. Likewise with the Kalda (2011), it was stated that the duration of diabetes mellitus was significantly associated with the quality of life of patients with diabetes mellitus, which generally had a low quality of life in the long duration of diabetes mellitus.

Someone who has diabetes mellitus will not be separated from co-morbidities which is a metabolic disease whose characteristics are hyperglycemia which occurs due to abnormal insulin secretion or insulin action. There are many complications in patients with Diabetes Mellitus such as diabetic foot ulcers.

Supported by the theory (ADA, 2011) that diabetes mellitus is a group of metabolic diseases with characteristics of hyperglycemia that occur due to abnormal insulin secretion, insulin work or both. Which can potentially affect a variety of severe complications such as acute complications and severe complications.

\section{Differences of physical dimensions in the quality of life of patients with Diabetes Mellitus in the treatment group (hyperbaric therapy for 10 days) with the control group (hyperbaric therapy for 5 days)}

After analyzing the data it was found that there was difference between 2 groups given 10 days hyperbaric oxygen therapy and 5 days oxygen therapy using the Independent t-test. Therefore it can be concluded that there are differences after being given 10-day hyperbaric oxygen therapy and 5-day hyperbaric oxygen therapy. All respondents in the treatment group experienced an increase in quality of life with a difference of (2-7) after being given hyperbaric oxygen therapy for 10 days with mean: 16.43 before treatment increased to Mean: 20.57 after treatment. Whereas in the control group 6 respondents experienced an increase (1-2) and 1 respondent did not experience improvement / remained after being given hyperbaric oxygen therapy for 5 days with mean: 16.00 before treatment increased to mean: 16.8571 after treatment. Consequently, it can be concluded that the longer the duration of administration of hyperbaric oxygen therapy the better the quality of life of the physical dimension in patients with diabetes mellitus

According to Wibowo (2015) explained that the provision of hyperbaric oxygen therapy (HBO) in patients with diabetes mellitus with gangrene wounds with a duration of 3 to 4 sessions can improve wounds and good wound care can improve 
tissue damaged by hypoxia. Where the administration of oxygen with high pressure will be able to supply the needs of tissues that are injured in nutrients and $\mathrm{O} 2$. Therefore, good perfusion improvement will help the healing process.

Hyperbaric oxygen therapy (HBOT), the administration of $100 \%$ oxygen at pressures greater than 1.4 atmosphere absolute in a series of treatments, can be used as an adjunctive therapy in many wound care settings because it improves oxygenation and neovascularization and decreases inflammation in chronic wounds (Lam, Fontaine, Ross, \& Chiu, 2017).

It was seen that after being given hyperbaric oxygen therapy for 10 days with a pressure of $2.4 \mathrm{~atm}$ for 90 minutes to 2 hours it could experience a significant increase. In this study, researchers gave hyperbaric oxygen therapy for 10 days in the treatment group and administered a questionnaire before being given hyperbaric oxygen therapy and measured the quality of life again by giving the same questionnaire after hyperbaric oxygen therapy was given. Differences obtained before and after being given hyperbaric oxygen therapy and from these results obtained an increase in the quality of life of patients with diabetes mellitus after being given hyperbaric oxygen therapy.

One effort to overcome the decline in quality of life is the provision of additional therapy such as hyperbaric oxygen therapy. Hyperbaric oxygen therapy is the administration of oxygen with a pressure of more than 1 (one) atmosphere, which is carried out in the High Pressure Air Chamber (RUBT). air pressure increases up to three times higher than normal air pressure. Under these conditions, the lungs can collect more pure oxygen inhaled. Blood flow will carry oxygen throughout the body and stimulate the release of substances called stem cells which will then stimulate healing. With high pressure conditions, it is expected that oxygen saturation increases and the cellular matrix that supports life gets optimal conditions.
Besides being able to heal wounds but also can reduce blood glucose in patients with diabetes mellitus. This is in accordance with the theory of the (Rachmawati, 2017), stating that high pressure oxygen in the therapy of 2.4 ATA TOHB for 90 minutes and interspersed for 10 minutes of rest in patients with diabetes mellitus, there is an oxphos (oxidative phospholrilation) in the $\beta$ cell mitochondria pancreas increases. In this process it results in an increase in blood insulin levels, decreased blood glucose levels, formation of aldimine levels and a decrease in the formation of ketoamine and $\mathrm{HbA} 1 \mathrm{c}$ levels.

From the results of the study it can be concluded that the duration of administration of hyperbaric therapy is 10 days more effective than 5 days. The longer the provision of hyperbaric oxygen therapy is also good physical condition that can be felt by people with diabetes mellitus. This is supported by Huda's research (2010) that the provision of hyperbaric oxygen therapy for 4 treatment sessions only reached $66.7 \%$ healing from the onset of diabetic foot wounds, after being given 5 treatment sessions the $90 \%$ wound healing process was good both from the initial wound condition. This is in line with research by Wibowo (2015) explaining that the provision of hyperbaric oxygen therapy (HBO) in patients with diabetes mellitus with gangrene wounds with a duration of 3 to 4 sessions can improve wounds and good wound care can repair damaged tissue due to hypoxia. Where the administration of oxygen with high pressure will be able to supply the needs of tissues that are injured in nutrients and $\mathrm{O} 2$. Therefore, good perfusion improvement will help the healing process. Consequently, it can be concluded that the longer the duration of administration of hyperbaric oxygen therapy the better the quality of life of the physical dimension in patients with diabetes mellitus. 


\section{CONCLUSION}

Based on the research that has been done, the following conclusions can be drawn:

There are differences in the physical dimensions of quality of life in the treatment group before and after being given hyperbaric therapy for 10 days at the Indonesian Navy Marine Health Institute Drs. Med. R. Rijadi S., Phys Surabaya.

There were no differences in the physical dimensions of quality of life in the control group before and after being given hyperbaric therapy for 5 days at the Indonesian Navy Marine Health Institute Drs. Med. R. Rijadi S., Phys Surabaya.

There are differences of the physical dimensions in the quality of life of patients with diabetes mellitus in the treatment group (hyperbaric therapy for 10 days) with the control group (hyperbaric therapy for 5 days) at the Indonesian Navy Marine Health Institute Drs. Med. R. Rijadi S., Phys Surabaya.

\section{REFERENCES}

American Diabetes Association. (2015). Standars Of Medical Care In Diabetes 2015. The Journal of CLinical and Applied Research and Education, 38(January), 99. http://doi.org/10.2337/dc15-S005

Brunner \& Suddarth. (2013). Buku Ajar Keperawatan Medikal. Ed 8. Vol 2 Jakarta: EGC

Hidayat., aziz., Alimul. (2011). Metodelogi Kesehatan Paradigma Kuantitatif. Surabaya: Health Books Publishing.

Huda, Nuh. (2010). Pengaruh Hiperbarik Oksigen (HBO) Terhadap Perfusi Perifer Luka Ganggren pada Penderita Diabetes Mellitus di RSAL Dr. Ramelan Surabaya, Tesis, Fakultas Keperawatan Universitas Indonesia. Depok. Diakses pada tanggal 15 November 2017.
Jang, Y., Hsieh, C. L., Wang, Y. H., \& Wu, Y. H. (2004). A validity study of the WHOQOL-BREF assessment in persons with traumatic spinal cord injury. Archives of Physical Medicine and Rehabilitation, 85(11), 18901895.

http://doi.org/10.1016/j.apmr.2004.02. 032

Kalda, R., Rätsep, A., \& Lember, M. (2008). Predictors of quality of life of patients with type 2 diabetes. Patient Preference and Adherence, 2, 21-26.

Lam, G., Fontaine, R., Ross, F. L., \& Chiu, E. S. (2017). Hyperbaric oxygen therapy: Exploring the clinical evidence. Advances in Skin and Wound Care. https://doi.org/10.1097/01.ASW.0000 513089.75457.22

Löndahl, M., Katzman, P., Nilsson, A., \& Hammarlund, C. (2010). Hyperbaric oxygen therapy facilitates healing of chronic foot ulcers in patients with diabetes. Diabetes Care, 33(5), 9981003. http://doi.org/10.2337/dc091754

Ogurtsova, K., Linnenkamp, U., Guariguata, L., Whiting, D., Shaw, J., \& da Rocha Fernandes, J. (2015). IDF Diabetes Atlas: Estimates for 2015 and 2040. Diabetes Research and Clinical Practice.

Rachmawati., Dhian., Satya. (2017). Terapi oksigen hiperbarik dalam perubahan kadar glukosa darah pasien Diabetes Mellitus di LAKESLA Drs. Med. R Rijadi, S. Phys Surabaya. Jurnal Proseding Hefa, [e-jurnal] (2581-2270): pp.134-141. Diakses pada tanggal 19 Juli 2018.

Riskesdas. (2013). Hasil Riskesdas 2013. Kemenkes RI (Vol. 38).

Sunjaya., I. N. (2009). Pola konsumsi makanan tradisional Bali sebagai faktor risiko kejadian diabetes melitus 
tipe 2 di Kabupaten Tabanan. Skala Husada, $6, \quad 75-81$. http://doi.org/10.1021/ja00839a026

Tulloch-Reid, M. K., \& Walker, S. P. (2009). Quality of life in Caribbean youth with diabetes. West Indian Medical Journal, 58(3), 250-256.

Wibowo, A. (2015). Oksigen Hiperbarik: Terapi Percepatan Penyembuhan Luka. Fakultas Kedokteran, Universitas Lampung Abstrak, 5, 125128.

Yusra, A. (2011). Hubungan antara dukungan keluarga dengan kualitas hidup pasien diabetes mellitus tipe 2 di poliklinik penyakit dalam rumah sakit umum pusat fatmawati Jakarta. Tesis.

Wändell, P. E. (2005). Quality of life of patients with diabetes mellitus: An overview of research in primary health care in the Nordic countries. Scandinavian Journal of Primary Health Care. http://doi.org/10.1080/028134305100 15296

WHO. (2016). Global Report on Diabetes. France 